\title{
Antimicrobial effect of probiotic Lactobacillus spp. on Pseudomonas aeruginosa
}

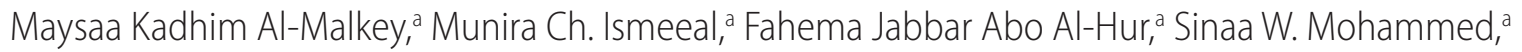 \\ Hanan J. Nayyefa
}

\author{
${ }^{2}$ Tropical-Biological Research Unit, College of Science, University of Baghdad, Iraq. \\ Correspondence to Maysaa Kadhim Al-Malkey (email: maysakadhim@uobaghdad.edu.iq). \\ (Submitted: 05 January 2017 - Revised version received: 17 January 2017 - Accepted: 22 February 2017 - Published online: 26 June 2017)
}

\begin{abstract}
Objectives Study the antimicrobial effect of probiotics produced from Lactobacillus rhamnosus GG and Lactobacillus acidophilus on Pseudomonas aeruginosa isolated from burn and wound infection and their ability of protease production.

Methods Swab samples were collected from 70 patients admitted at Burns Center/Al-Yarmouk Teaching Hospital. Primary bacterial identification cultured on differential selective media and biochemical tests were done. The Vitek2 compact system (Biomerieux, France) was used to confirm the P. aeruginosa isolates by Gram negative identification card and the antimicrobial susceptibility Test Card to each isolate was performed. Protease production using skimmed milk agar $1 \%$ was performed. Crud bacteriocin produced from L. acidophilus (Holland \& Barrett, USA) and L. rhamnosus (Health Gensis, USA) was extracted during log phase using MRS broth (24 h/ 370 C/ 5-10\% CO $)$, then cool centrifugation was done (6000 rpm at $4^{\circ} \mathrm{C}$ for $10 \mathrm{~min}$ ). Protein concentration of bacteriocin was estimated using Bradford assay using bovine serum albumin as standard.

Results Only 31 out of 48 isolates were identified as P. aeruginosa; 9 (45\%) from wound and 22 (79\%) from burn swabs. Antimicrobial susceptibility tests included 16 antibiotics; P. aeruginosa isolates showed multi-drug resistance for antibiotics. All P. aeruginosa isolates were having the ability for protease enzyme production. Antimicrobial effect of bacteriocin produced by L. acidophilus and L. rhamnosus on protease using plate diffusion method showed positive results. Protein concentration of bacteriocin produced by L. rhamnosus and L. acidophilus were $74 \mathrm{mg} / \mathrm{mL}, 44 \mathrm{mg} / \mathrm{mL}$, respectively. The highest zone of antimicrobial effect by L. rhamnosus was $32 \mathrm{~mm}$ and by L. acidophilus was $25 \mathrm{~mm}$ using well diffusion method.

Conclusions P. aeruginosa showed a multi-drug resistance and had the ability to produce protease enzyme. Bacteriocin produced by L. acidophilus and L. rhamnosus showed an acceptable positive results to be used as potential alternative bio-remedy to overcome the multi-drug resistance dilemma.

Keywords antimicrobial effect, Lactobacillus spp., bacteriocin, Pseudomonas aeruginosa, protease
\end{abstract}

\section{Introduction}

Pseudomonas aeruginosa is a Gram-negative aerobic bacilli and the natural flora of the skin and intestinal tract that is also found in water and soil. It is an opportunistic pathogen and one of the main causes of nosocomial infections causes severe diseases like cystic fibrosis, urinary tract infections, acute purulent meningitis, otitis media, otitis external, eye infections, wound and burn infections, septicaemia and infantile diarrhea. ${ }^{1}$ The multiple resistant to the most commonly used antibiotics is quite common in $P$. aeruginosa due to possession of high number of virulence factors, which is attributable to a concerted action of multidrug efflux pumps with a chromosomally encoded antibiotic resistance genes and the low permeability of bacterial cellular envelopes as well as biofilm formation phenomenon. ${ }^{2}$ Wound infections due to $P$. aeruginosa are especially difficult in burn patients, high percentage of wound infections will lead to sepsis with significant mortality rates. ${ }^{3}$ Protease-deficient strains are generally less virulent than protease producers in burned mouse models. ${ }^{4}$ Proteases are enzymes that can hydrolyze peptide bonds within peptides and proteins. $P$. aeruginosa secretes several proteases (protease IV, elastase B, elastase A, and alkaline protease), which play an important role during infection with $P$. aeruginosa and are a characteristic for invasiveness as determined in clinical strains. ${ }^{5}$ These proteases are able to degrade a whole range of biological important host proteins such as fibrinogen, elastin, collagen and plasminogen as well as immunoglobulin $\mathrm{G}$ (IgG) and the complement components 3 and
C1q, which belong to the immune defense system. ${ }^{6}$ So, there is a considerable interest in developing low cost large-scale alternative remedies to prevent or reduce the multi-drug resistance of $P$. aeruginosa. In this regard, probiotics may close the therapeutic gap. Probiotics are living microbial species, when administered in adequate amounts confer a health benefit to the host. ${ }^{7}$ Probiotics have been proven to be useful in the treatment of several infections and gastrointestinal diseases such as acute diarrhea. ${ }^{8}$ Multiple mechanisms have been proposed to justify the protective and therapeutic role of probiotics including lactose digestion, production of antimicrobial agents, pathogen exclusion and immunomodulation. ${ }^{9-11}$ Commercially available probiotic preparations including lactic acid bacilli (Lactobacillus rhamnosus, Lactobacillus acidophilus, L. plantarum, L. cassei, etc.) alone or in combination with Streptococcus and Saccharomyces species have shown the beneficial effects. ${ }^{12}$ Lactobacilli are known to produce a variety of metabolic by-products in addition to biosurfactants. Some of which have antimicrobial activity including lactic acid, hydrogen peroxide, bacteriocins, and bacteriocin-like substances which has imperative biomedical advantages..$^{13}$ Bacteriocins are ribosomally synthesized low-molecular weight peptides or proteins with potential use in food preservation due to their bactericidal effects on food spoilage and pathogenic organisms. ${ }^{14}$ Bacteriocins have unique applications in food processing and food safety because of their heat stability and sensitivity to proteolytic enzymes. ${ }^{15}$ 
The current study aimed to investigate the antimicrobial effect of the probiotic strains L. rhamnosus GG and L. acidophilus on $P$. aeruginosa isolated from wound and burn infection in vitro.

\section{Patients and Methods}

\section{Bacterial Isolation, Identification and Antimicrobial Resistance}

Swab samples were collected from 70 patients (both males and female with age range 1-64 years) admitted at Burns Center / Al-Yarmouk Teaching Hospital from the period November 2013 till February 2014. Primary bacterial identification cultured on differential and selective media then biochemical tests were done. The automated microbial identification using Vitek2 compact system (Biomerieux, France) was used to confirm the $P$. aeruginosa isolates by Gram Negative Identification Card (GN ID), which accommodates colorimetric reagent cards that are incubated and interpreted automatically and the Antimicrobial Susceptibility Test Card (AST) to each isolate was performed according to manufacturer's instructions.

\section{Protease Production}

Protease production by $P$. aeruginosa isolates using skimmed milk agar 1\% (Himedia, India) was performed to determine the proteolytic potency of the isolates using agar well diffusion assay. ${ }^{16}$

\section{Probiotic Preparation}

Probiotic strains from commercially available capsule $L$. acidophilus (Holland \& Barrett, USA) and L. rhamnosus GG (Health Gensis, USA) were isolated by suspending in each capsule in $10 \mathrm{ml}$ of MRS broth (Himedia, India) then incubated anaerobically at $37^{\circ} \mathrm{C}$ for $48 \mathrm{hr}^{17}$

\section{Antimicrobial Assay}

The antimicrobial spectrum from Lactobacilli spp. was determined using a loopful of each of the Lactobacilli isolates from the MRS agar slants was inoculated into tubes containing $10 \mathrm{~mL}$ of sterile MRS broth. These broth cultures were incubated anaerobically at $37^{\circ} \mathrm{C}$ for $48 \mathrm{hr}$. The following assays conducted as triplicate:

Well diffusion method: Sterile cotton swabs were dipped into the cultures of $P$. aeruginosa previously propagated in Brain Heart Infusion (BHI) broth (Difco, USA) for $24 \mathrm{hr}$ at $37^{\circ} \mathrm{C}$. The turbidity of the suspension was 0.5 McFarland and contained more than $10^{8}$ bacteria. The inoculated with $100 \mu \mathrm{l}$ of $\left(1.5 \times 10^{8} \mathrm{cfu} / \mathrm{ml}\right)$ by swabbing over the entire surface of the nutrient agar (Himedia, India) plates was made. Wells ( $6 \mathrm{~mm}$ diameter) were made on the cultured plates. Then $50 \mu \mathrm{l}$ of Lactobacilli spp. bacterial suspension was inoculated into wells. After $24 \mathrm{hr}$ of incubation at $37^{\circ} \mathrm{C}$, each plate was examined for the zone of inhibition. Control for each zone was prepared using un-inoculated sterile MRS broth as negative control and acetic acid (33\%) as positive control. ${ }^{18}$

Agar disc method: The above bacterial suspension of Lactobacillus spp. was incubated anaerobically on MRS agar at $37^{\circ} \mathrm{C}$ for $48 \mathrm{hr}$, agar discs with $(6 \mathrm{~mm})$ were made, then the agar discs were seeded on plates of nutrient agar cultured with $100 \mu \mathrm{l}$ of $\left(1.5 \times 10^{8} \mathrm{cfu} / \mathrm{ml}\right)$ of $P$. aeruginosa. The plates were incubated for $37^{\circ} \mathrm{C}$ for $24 \mathrm{hr}$. The diameters of the inhibitory zones were measured including the diameters of the discs to the nearest whole number. Control was prepared using agar disc free of bacterial growth. ${ }^{19}$

\section{Extraction of Crude Bacteriocin}

Crud bacteriocin produced from L. acidophilus and L. rhamnosus was extracted during log phase using MRS broth incubated anaerobically at $37^{\circ} \mathrm{C}$ for $24 \mathrm{hr}$. After incubation, the cultures were centrifuged $\left(6000 \mathrm{rpm}\right.$ at $4^{\circ} \mathrm{C}$ for $10 \mathrm{~min}$ ) to obtain culture-free supernatant which was filtered using $0.22 \mu \mathrm{m}$ pore sterilized filter. The $\mathrm{pH}$ was adjusted to $\mathrm{pH} 7$ with $1 \mathrm{M} \mathrm{NaOH} .{ }^{20}$

\section{Determination of Protein Content}

Protein content was determined using colorimetric at maximum absorption at $600 \mathrm{~nm}$, using brilliant blue G-250 and Bovine Serum Albumin. ${ }^{21}$

\section{Antimicrobial Activity of Bacteriocin on Protease Production}

The antimicrobial spectrum from bacteriocin was determined using a loopful of $P$. aeruginosa isolates from the BHI agar slants that was inoculated into tubes containing $5 \mathrm{~mL}$ of sterile BHI broth. These broth cultures were incubated at $37^{\circ} \mathrm{C}$ for $24 \mathrm{hr}$. The well diffusion assay conducted as triplicate. They inoculated with $10 \mu \mathrm{l}$ of $\left(1 \times 10^{8} \mathrm{cfu} / \mathrm{ml}\right)$ by swabbing over the entire surface of the skimmed milk agar plates. Wells (6 mm diameter) were made on the cultured plates. Then $10 \mu \mathrm{l}$ of bacteriocin was inoculated into wells. After $24 \mathrm{hr}$ of incubation at $37^{\circ} \mathrm{C}$, each plate was examined for the zone of inhibition. Control for each zone was prepared using un-inoculated sterile BHI broth as negative control and phosphate saline (0.1 M/PH 7.0) as positive control.

\section{Statistical Analysis}

The data are shown as the mean \pm standard deviation (SD, $n=5)$. The results obtained were analyzed using SPSS 18.0 program for Windows and by analysis of variance (ANOVA) with significance level set at $P=0.05$.

\section{Results}

From 70 swabs obtained from contaminated burn and wound infection, only $48(69 \%)$ isolates were positive for primary bacterial isolation. Only 31 (65\%) isolates out of 48 were identified as $P$. aeruginosa (9 wound infection and 22 burn infection) $(P \leq 0.01)$. Antimicrobial susceptibility tests included 16 antibiotics (Table 1 ).

Out of $31 P$. aeruginosa isolates, 20 isolates showed multidrug resistant for antibiotics (Table 2$)(P \leq 0.01)$.

All the 20 multi-drug resistant $P$. aeruginosa isolates were having the ability for protease production with potency (Table 3); $(P \leq 0 / 05)$. Figure 1 shows protease production for the isolate-11 and isolate- 19 with duplicates.

Antimicrobial effect of Lactobacilli spp. on P. aeruginosa using agar disc and well diffusion method, (isolate-8, 11 and 19) were selected due to their high protease production and multi-drug resistance to many antibiotic. The inhibition zone was measured by millimeters as in Table 4 . Statistically, the results were significant $(P \leq 0.05)$. The highest inhibition zone was by $L$. rhamnosus than $L$. acidophilus in all isolates in both methods.

The highest inhibition zone by L. rhamnosus was $20 \mathrm{~mm}$ on isolate-19, on isolate-11 was $25 \mathrm{~mm}$, respectively; meanwhile, 


\begin{tabular}{|c|c|c|}
\hline No. & Antimicrobial & Resistant percentage (\%) \\
\hline 1 & Piperacillin & 100 \\
\hline 2 & Ticarcillin & 100 \\
\hline 3 & Ticarcillin clavoulanic acid & 100 \\
\hline 4 & Cefazolin & 100 \\
\hline 5 & Ceftriaxone & 100 \\
\hline 6 & Tigecycline & 100 \\
\hline 7 & Piperacillin Tazobactam & 80 \\
\hline 8 & Amikacin & 65 \\
\hline 9 & Gentamycin & 80 \\
\hline 10 & Tobramycin & 85 \\
\hline 11 & Imipenem & 70 \\
\hline 12 & Meropenem & 70 \\
\hline 13 & Cefepime & 60 \\
\hline 14 & Ceftazidime & 50 \\
\hline 15 & Ciprofloxacin & 75 \\
\hline 16 & Levaofloxacin & 75 \\
\hline
\end{tabular}

\begin{tabular}{lcc}
\hline $\begin{array}{c}\text { Table 2. } \begin{array}{c}\text { Multi antimicrobial resistant by Pseudomonas } \\
\text { aeruginosa isolates }\end{array} \\
\text { Number of antimicrobial }\end{array}$ & Resistant P. aeruginosa isolates \\
\cline { 2 - 3 } & No. & $\%$ \\
\hline 4 & 2 & 10 \\
5 & 2 & 10 \\
8 & 2 & 10 \\
9 & 1 & 5 \\
12 & 1 & 5 \\
13 & 5 & 25 \\
14 & 7 & 35 \\
Total & 20 & 100 \\
Chi square test $\left(\chi^{2}\right)$ & - & $9.017^{* *}$ \\
\hline
\end{tabular}

"* $P \leq 0.01$.

\begin{tabular}{lclc}
\multicolumn{4}{l}{ Table 3. Pseudomonas aeruginosa protease production potency } \\
\hline $\begin{array}{l}\text { No. of } \\
\begin{array}{l}\text { P. aeruginosa } \\
\text { isolates }\end{array}\end{array}$ & $\begin{array}{c}\text { Protease } \\
\text { production }\end{array}$ & $\begin{array}{l}\text { No. of } \\
\text { P. aeruginosa } \\
\text { isolates }\end{array}$ & $\begin{array}{c}\text { Protease } \\
\text { production }\end{array}$ \\
\hline Isolate-1 & ++ & Isolate-11 & ++ \\
Isolate-2 & + & Isolate-12 & + \\
Isolate-3 & + & Isolate-13 & ++ \\
Isolate-4 & + & Isolate-14 & + \\
Isolate-5 & +++ & Isolate-15 & ++ \\
Isolate-6 & + & Isolate-16 & + \\
Isolate-7 & + & Isolate-17 & +++ \\
Isolate-8 & +++ & Isolate-18 & + \\
Isolate-9 & ++ & Isolate-19 & ++ \\
Isolate-10 & + & Isolate-20 & + \\
\hline
\end{tabular}

+: Mild protease production; ++: Moderate protease production; +++: High protease production.

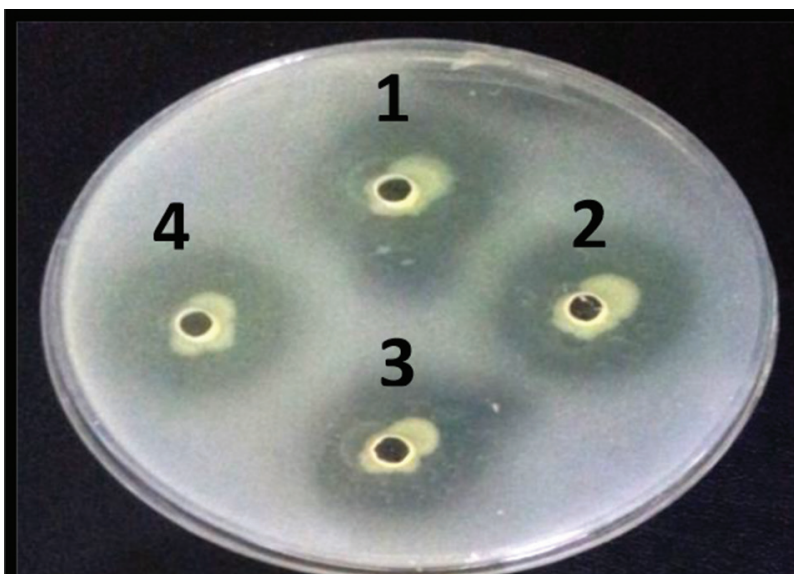

Fig. 1 Pseudomonas aeruginosa on skimmed milk agar 1\%. (1 and 2) = duplicate of isolate-11; (3 and 4) = duplicate of isolate-19 using well diffusion method.

highest inhibition zone by L. acidophilus was $18 \mathrm{~mm}$ on isolate-19 using agar disc method as shown in Fig. 2.

The highest inhibition zone of bacterial suspension by L. rhamnosus was $27 \mathrm{~mm}$ on both isolate-11 and isolate-19; meanwhile, highest inhibition zone by L. acidophilus was $18 \mathrm{~mm}$ on isolate-19 using well diffusion method as shown in Fig. 3.

The highest inhibition zone of bacterial supernatant on isolate-19 by both $L$. rhamnosus and $L$. acidophilus was 32 $\mathrm{mm}, 25 \mathrm{~mm}$, respectively, using well diffusion method as shown in Fig. 4.

Protein concentration of crud bacteriocin produced by L. rhamnosus GG and L. acidophilus were $74 \mathrm{mg} / \mathrm{mL}, 44$ $\mathrm{mg} / \mathrm{m} / \mathrm{L}$, respectively. Fig. 5 shows the inhibitory effect of crud bacteriocin extracted from L. rhamnosus GG and L. acidophilus on protease production by $P$. aeruginosa (isolates- 11 and 19) cultured on skimmed milk agar $1 \%$ after treated with crud bacteriocin comparing to untreated isolates.

\section{Discussions}

$P$. aeruginosa is one of the important bacteria that can cause huge burdens for public health today due to its ability to adapt its genome and physiology during chronic infections. Major features making it a very successful opportunistic pathogen includes: virulence factors, biofilm formation, motility and quorum sensing. ${ }^{22}$ According to Arqués et al. (2015) determining the antagonistic effect of probiotics on the growth of $P$. aeruginosa and the effectiveness of various bacteriocins of probiotics may be hindered by the proteolytic activity of microbial enzymes that are secreted only during active fermentation. ${ }^{23}$ The present study basically focused on the bacteriocin, which is produced by a commercially available of L. rhamnosus GG and L. acidophilus. Bacteriocins, in general, share a narrow spectrum of antimicrobial activity; however, there are certain bacteriocins that exhibit a broad spectrum of antibacterial activity and are also capable of targeting viruses, protozoa and even fungi. ${ }^{2}$

The results revealed that, the probiotics of L. rhamnosus showed enhancement of inhibitory zone diameters in agar disc and well diffusion method (bacterial suspension and supernatant) rather than L. acidophilus. The narrow inhibitory zone using the agar disc method may be due to the limited number of the Lactobacilli cultured on MRS disc leading to its limited antimicrobial activity which come in accordance with 


\begin{tabular}{|c|c|c|c|c|c|c|c|c|c|c|}
\hline \multirow{4}{*}{$\begin{array}{l}\text { LSD } \\
\text { value }\end{array}$} & \multicolumn{9}{|c|}{ Inhibition zones (MM) } & \multirow{4}{*}{ Isolate } \\
\hline & \multirow{3}{*}{$\mathrm{CO}^{-}$} & \multicolumn{6}{|c|}{ Well diffusion method } & \multirow{3}{*}{\multicolumn{2}{|c|}{$\begin{array}{c}\begin{array}{c}\text { Agar disc } \\
\text { method }\end{array} \\
\text { L.acidophilus }\end{array}$}} & \\
\hline & & \multicolumn{4}{|c|}{ Supernatant } & \multicolumn{2}{|r|}{ Suspension } & & & \\
\hline & & $\mathrm{CO}^{+}$ & L.rhamnosus & L. acidophilus & $\mathrm{CO}^{+}$ & L.rhmanosus & L. acidophilus & & & \\
\hline $7.02^{*}$ & 5 & 30 & 25 & 15 & 30 & 24 & 12 & 24 & 16 & P8 \\
\hline $9.13^{*}$ & 5 & 33 & 30 & 18 & 31 & 27 & 16 & 25 & 16 & P11 \\
\hline $7.53^{*}$ & 5 & 30 & 32 & 25 & 31 & 27 & 20 & 20 & 18 & P19 \\
\hline - & $0.00 \mathrm{NS}$ & 6.02 NS & $5.71^{*}$ & $6.38^{*}$ & $6.72 \mathrm{NS}$ & $5.22^{*}$ & $5.19^{*}$ & $5.83^{*}$ & $6.59^{*}$ & LSD value \\
\hline
\end{tabular}

${ }^{*} P \leq 0.05$; NS: Non significant; $\mathrm{CO}^{+}$: Control positive (33\% Acetic acid); $\mathrm{CO}^{-}$: Control negative (un-cultivated MRS broth).

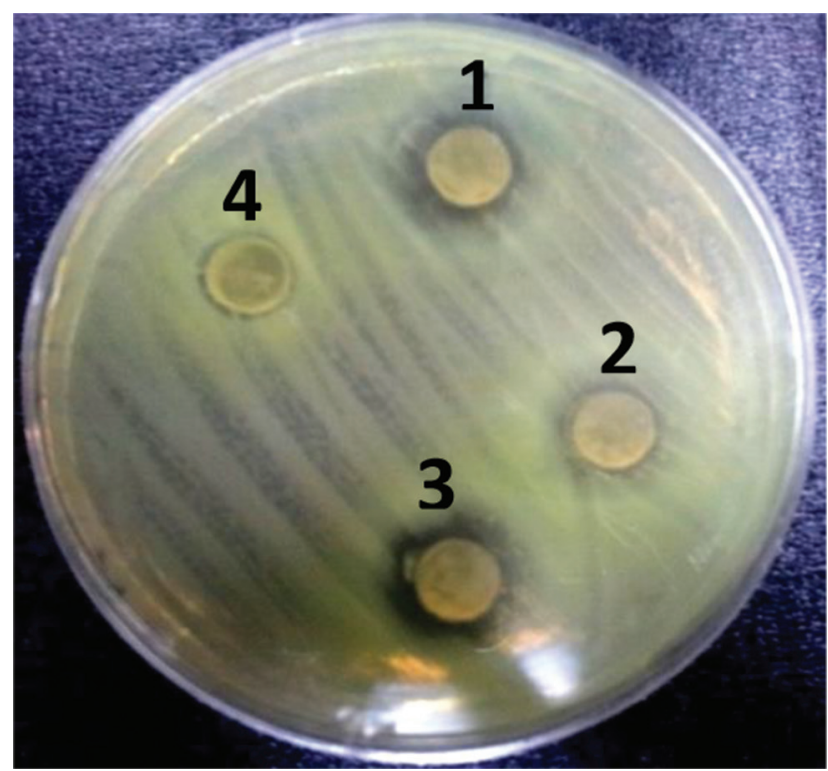

Fig. 2 Antimicrobial effect of Lactobacilli spp. on P. aeruginosa (isolate-11, 19) using agar disc method. (1) L. acidophilus; ( 2 and 3 ) duplicate of L. rhamnosus GG; (4) Negative control (un-cultivated MRS broth) using agar diffusion method.

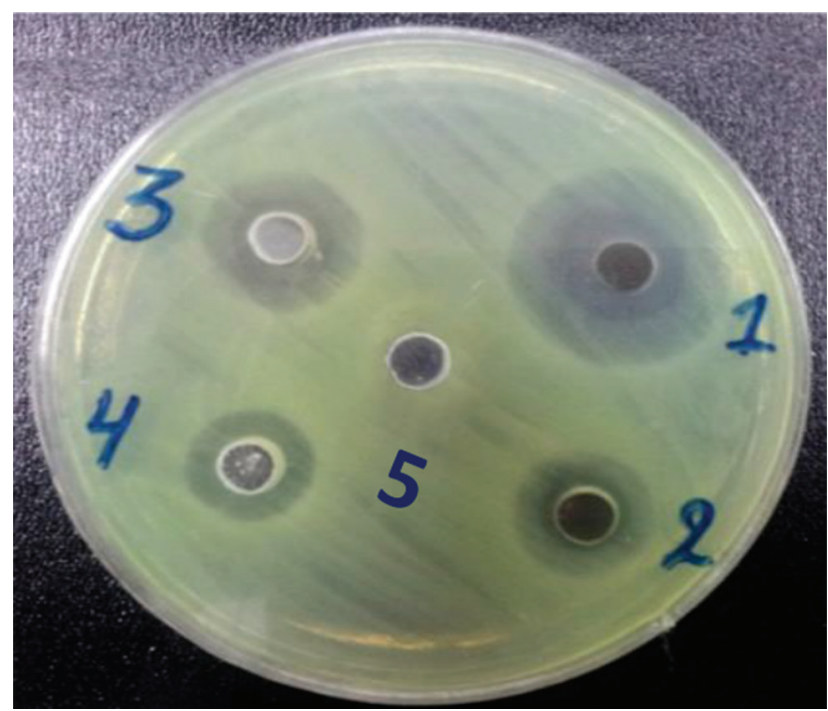

Fig. 3 Antimicrobial effect of bacterial suspension (Lactobacilli spp.) on Ps. aeruginosa (isolate-11, 19) using well diffusion method. (1) Positive control (33\% Acetic acid); (2) L. acidophilus; (3 and 4) L. rhamnosus GG (duplicate); (5) Negative control (un-cultivated MRS broth).

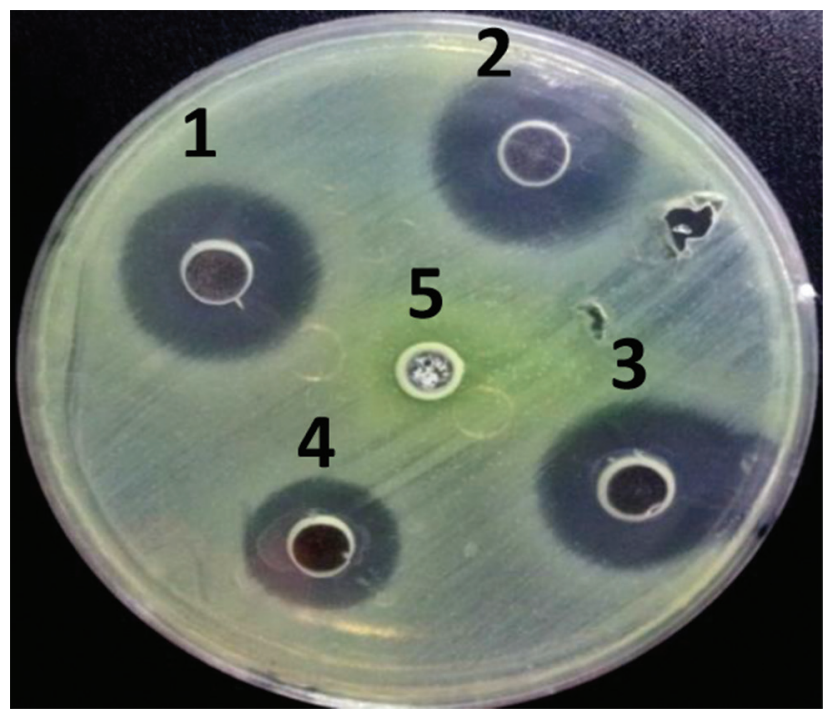

Fig. 4 Antimicrobial effect of bacterial supernatant (Lactobacilli spp.) on P. aeruginosa (isolate-19) using well diffusion method. (1 and 2) L. rhamnosus GG (duplicate); (3) L. acidophilus; (4); Positive control (33\% Acetic acid); (5) Negative control (un-cultivated MRS broth).

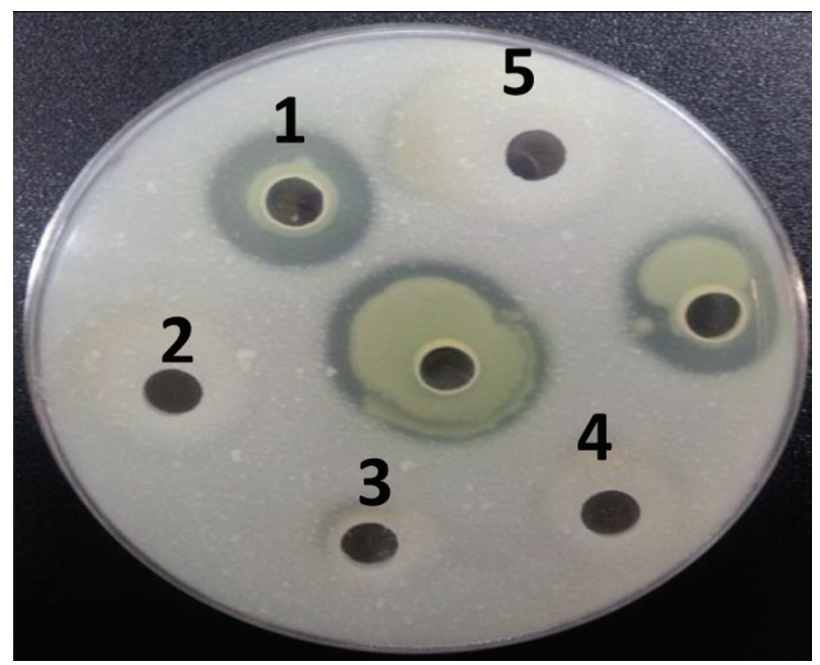

Fig. 5 Inhibitory effect of crud bacteriocin produced by Lactobacilli on protease production from $P$ s. aeruginosa. (1) Positive control (P. aeruginosa, isolate-19); (2) Negative control (un-cultivated Brain Heart broth); (3) P. aeruginosa isolate-11 treated with crud bacteriocin from L. rhmanosus; (4) P. aeruginosa isolate- 19 treated with crud bacteriocin from L. rhmanosus; (5) P. aeruginosa isolate-19 treated with crud bacteriocin from $L$. acidophilus. 
Paluszak et al. (2007). ${ }^{19}$ The antimicrobial effect of bacterial suspension using well diffusion method showed more clearly inhibitory zone in diameters, the competitive exclusion between the pathogenic bacteria as well as to the presence of other secondary metabolites by Lactobacilli spp. such as the lactic acid, biosurfactant, and other fermentation product as well as bacteriocin may play a major role. ${ }^{25}$

The highest inhibitory zone was recorded using free cell supernatant which have remarkable potential for their antimicrobial activities which comes in compatible with a study by Daba and Saidi (2015) which study the inhibitory activity of bacteriocin producing lactic acid bacteria (LAB) that isolated from raw milk against $P$. aeruginosa and Escherichia coli using free cell supernatant and cell diffusion method. ${ }^{26}$ Wala'a and Nibras (2013) found that bacteriocins from L. acidophilus exhibited activity against Serratia marcescens and that bacteriocin of L. acidophilus was stable at $\mathrm{pH} 4,7$ half of its activity was lost at $\mathrm{pH} 8$ and whole activity was lost at other $\mathrm{pH}$ values. ${ }^{27}$ Gho and Philip (2015) focus on isolate and purify the bacteriocin of Weissella confusa A3 from cow milk was shown to have inhibitory activity towards pathogenic bacteria as Bacillus cereus, E. coli, P. aeruginosa and Micrococcus luteus. The bacteriocin was shown to be heat stable and functioned well at low pH (2 to 6). Reduction of activity was shown after treatment with proteinase $K$, trypsin and peptidase that confirmed the proteinaceous nature of the compound. ${ }^{28}$

Ismaeel et al. (2013) investigated the biological applications of surlactin derived from $L$. acidophilus using different pathogenic strains and toward to in vitro (contact lenses) and in vivo (rabbits' eyes). Their results demonstrated the capability of surlactin to inhibit the adhesion of pathogens up to $60 \%$ without any antibacterial activity against Staphylococcus auerus using well diffusion method. The surlactin proved to be effective for treating the infection in rabbits' eyes with $P$. aeruginosa and that infection with $P$. aeruginosa (administrated to rabbits' eyes) can be prevented by using surlactin. ${ }^{29} \mathrm{~A}$ study by Zho et al., (2015) revealed that bacteriocin from $L$. acidophilus XH1 inhibited E. coli, S. aureus and B. anthracis. It showed a wide range of antimicrobial activity at $\mathrm{pH} 1.0-5.0$ while at $37-120^{\circ} \mathrm{C}$, it was sensitive to trypsin, pepsin and papain, but insensitive to proteinase $\mathrm{K}$ and neutral protease. ${ }^{30}$

Many antibiotics, antimicrobial agents do possess protein as one of the major functioning fractions of the entire molecule.
The proteinaceous nature or peptides do contribute toward antimicrobial activity and have tremendous potential for treating and/or preventing the infectious diseases. Risk of microbial resistance can be reduced certainly with the help of such proteinaceous molecules. Protein rich with and without polysaccharide, phosphate fractions in cell-bound or cell-associated biosurfactant originated from Lactobacillus spp. have undoubtedly fulfilled this expectation proving to combat pathogens. Brzozowski et al. (2011) reported biosurfactant production by L. fermenti 126 and L. rhamnosus CCM 1825 having proteinaceous biosurfactant with an existence of polysaccharide and phosphates biosurfactant obtained L. rhamnosus CCM 1825 possessed more proteins and phosphates as compared with $L$. fermenti $126 .{ }^{31}$

Antimicrobial effect of bacteriocin production may contribute to probiotic functionality through three different mechanisms: firstly, as colonising peptides; secondly, bacteriocins function through direct inhibition of the growth of pathogens9; and finally, bacteriocins may serve as signalling peptides/quorum-sensing molecules in the intestinal environment. ${ }^{32}$ Bacteriocin can interfere with the bacterial cell wall enzyme production leading to inhibit their virulence factors such as potency of protease production. ${ }^{33}$

\section{Conclusions}

In an effort to establish a new antimicrobial agent from lactic acid bacteria, novel strains capable of utilizing cheaper, renewable substrates, greater yields, and novel applications, which may act as bacteriostatic or bactericidal agents. Using probiotic bacteria toward therapeutic approaches can be highly significant in preventing and/or dealing with hospital-acquired infections may be an important undertaking.

\section{Acknowledgements}

The author would acknowledge all the patients whom participate in this study and donate the samples in spite of their suffering.

\section{Conflict of Interest}

The authors declare no conflicts of interest.

\section{References}

1. Driscoll JA, Brody SL, Kollef MH. The Epidemiology, Pathogenesis and Treatment of Pseudomonas aeruginosa Infections. Drugs. 2007; 67:351-368.

2. Drenkard E. Antimicrobial resistance of Pseudomonas aeruginosa biofilms. Microbes Infect. 2003;5:1213-1219.

3. Murray PR, Baron EJ, Pfaller MA, et al. Manual of Clinical Microbiology. $2^{\text {nd }}$ ed Washington, Md: American Society Microbiology; 1999

4. Holder IA, Haidaris CG. Experimental studies of the pathogenesis of infections due to Pseudomonas aeruginosa: extracellular protease and elastase as in vivo virulence factors. Can J Microbiol. 1979;25:593-599.

5. Janda JM, Bottone EJ. Pseudomonas aeruginosa enzyme profiling: predictor of potential invasiveness and use as an epidemiological tool. J Clin Microbiol. 1981:14:55-60.

6. Engel LS, Hill JM, Caballero AR, et al. Protease IV, a unique extracellular protease and virulence factor from Pseudomonas aeruginosa. J Biol Chem. 1998;273:16792-16797

7. Fuller R. probiotics in human medicine. Gut. 1991:32:439-442

8. Mazmanian SK, Round JL, Kasper DL. A microbial symbiosis factor prevents intestinal inflammatory disease. Nature. 2008:453:620-625.

9. Gibson GR, Probert HM, Van Loo J, and Rastall RA. Dietary modulation of the human colonic microbiota: updating the concept of prebiotics. Nut Res Rev. 2004;17:259-275.

10. Syukur S, Bisping B, Noli ZA, Purwati E. Antimicrobial properties and Lactase activities from selected probiotic Lactobacillus brevis associated with green cacao fermentation in West Sumatra, Indonesia. J Prob Health. 2013:1:113.

11. Jamalifar H, Rahimi HR, Samadi N, et al. Antimicrobial activity of different Lactobacillus species against multi-drug resistant clinical isolates of Pseudomonas aeruginosa. Iran J Microbio. 2011;3:21-25.

12. Saggioro A. Probiotics in the treatment of irritable bowel syndrome. J Clin Gastroenterol. 2005:38:S104-106.

13. Choi EA, Chang HC. Cholesterol-lowering effects of a putative probiotic strain Lactobacillus plantarum EM isolated from kimchi. LWT - Food Sci Technol. 2015;62:210-217.

14. Cheikhyoussef A, Pogori N, Chen HQ et al. Antimicrobial activity and partial characterization of bacteriocin-like inhibitory substances (BLIS) produced by Bifidobacterium infantis BCRC 14602. Food Control. 2009:20:553-559. 
15. Jiang J. Shi B, Zhu D, et al. Characterization of a novel bacteriocin produced by Lactobacillus sakei LSJ618 isolated from traditional Chinese fermented radish. Food Control. 2012;23:338-344.

16. Kannan N. Laboratory manual in general microbiology. New Delhi: Panima Publishing Corporation; p.135. 2002

17. Forbes BA, Daniel FS, Alice SW. Bailey and Scott's diagnostic microbiology. 12th ed., Mosby Elsevier Company, USA. 2007.

18. Clinical and Laboratory Standards Institute (CLSI). Performance Standards for Antimicrobial Discs Susceptibility tests: Approved standards (M02-A12), Informational supplements (M100-S25); 25 $5^{\text {th }}$ ed., 2015.

19. Paluszak Z, Kaszewska JE, Szala B. Inhibitory effect of lactic acid bacteria of genus lactobacillus on the survival of proteus and Shigella Rod in Mixed Culture. Bull Vet Inst Pulawy. 2007: 50:335-40.

20. Maqsood S, Hasan F, Masud T, Imran M. Preliminary characterisation of bacteriocin produced by Lactobacillus acidophilus TS1 isolated from traditional dahi. Ann Microbiol. 2008;58:617-622.

21. Bradford MM. A rapid and sensitive method for the quantitation of microgram quantities of protein utilizing the principle of protein-dye binding. Ann Biochem. 1976;72:248-254.

22. Cai Z, Liu Y, Chen Y, Yam JK. RpoN regulates virulence factors of Pseudomonas aeruginosa via modulating the PqsR quorum sensing regulator. Int J Mol Sci. 2015;16:28311-28319.

23. Arqués JL, Rodríguez E, Langa S, et al. Antimicrobial activity of lactic acid bacteria in dairy products and gut: effect on pathogens. BioMed Res Int. 2015;9. http://dx.doi.org/10.1155/2015/584183.

24. Rea MC, Ross RP, Cotter PD, et al. Classification of bacteriocins from gram positive bacteria. In: Prokaryotic Antimicrobial Peptides. From Genes to
Application. Drider, D. and Rebuffat, S. (eds). Springer, Berlin, pp. 29-54. 2011

25. Holzapfel W, Wood BJ. The genera of lactic acid bacteria: Springer Science \& Business Media. 2012

26. Daba H, Saidi S. Detection of bacteriocin-producing lactic acid bacteria from milk in various farms in north-east Algeria by a new procedure. Agron Resear. 2015;13:907-18.

27. Wala'a SHA, Nibras NM. Partial purification and characterization of bacteriocin produced by Lactobacillus acidophilus. J Biotech Resear Cent. 2013;7:80-86.

28. Gho HF, Philip K. Purification and characterization of bacteriocin produced by Weissella confusa A3 of dairy origin. PLoS ONE. 2015;10:1-17.

29. Ismeeal MCh, Ibrahim KM, and Al-Malikey MK. The effect of surlactin produced by Lactobacillus acidophilus on eye infectious bacteria in rabbits. J Baghdad Sci. 2013;10:133-142.

30. Zhao R, Duan G, Yang T, et al. Purification, characterization and antibacterial mechanism of Bacteriocin from Lactobacillus acidophilus XH1. Tropi J Pharm Res. 2015:14:989-95.

31. Brzozowski B, Bednarski W, Gołek P. The adhesive capability of two Lactobacillus strains and physicochemical properties of their synthesized biosurfactants. Food Technol Biotechnol. 2011;49:177-186.

32. Dobson A, Cotter PD, Ross RP, et al. Bacteriocin production: a probiotic trait? Appl Environ Microbiol. 2012;78:1-6.

33. Wiedemann I, Breukink E, Van Kraaij C, et al. Specific binding of nisin to the peptidoglycan precursor lipid II combines pore formation and inhibition of cell wall biosynthesis for potent antibiotic activity. J Biol Chem. 2001;276:1772-1779. 